\title{
GLL
}

$0 \square=0$ Geomatics, Landmanagement and Landscape No. 2 • 2021, 87-99

\section{REVIEW OF DTM DERIVATIVES MOST USED IN DIGITAL SOIL MAPPING}

\author{
Małgorzata Radło-Kulisiewicz
}

\begin{abstract}
Summary
Digital Soil Mapping (DSM) is a subdiscipline of pedology, where soil cover is modelled through use of spatial - temporal relations between environmental covariates and soil. The process of quantitative terrain description used in DSM is called terrain parametrization, where terrain attributes (morphometric factors, Digital Terrain Model derivatives) are the most used predicators. Terrain parameterisation was used as a tool in the hydrological survey workshop long before computers had been in use. With the development of digitisation, it also began to be used to determine selected soil attributes, which was greatly facilitated by GIS applications. A significant breakthrough in the importance of terrain attributes in the creation of soil maps and models took place with the formalisation of rules for digital soil mapping. Literature describes over 50 indices, although only a few of them are commonly applied. This applies to single soil attributes as well as more advanced implementations in more sophisticated models such as artificial intelligence algorithms. The aim of the following article is to present the main components of DSM and to describe characteristics of the most commonly derivatives of DTM applied there, also refers to several examples of the use of terrain parameters in the context of DSM in terms of the resolution of the elevation model used.
\end{abstract}

\section{Keywords}

digital soil mapping $\bullet$ DTM $\bullet$ terrain attributes $\bullet$ GIS

\section{Introduction}

Since ancient times, soil has been considered a substrate for plants, and its depth and layers have been classified in many ways [Strzemski 1957]. Due to advances in chemistry, geology, and petrography, at the turn of the18th and 19th centuries petrographic geological soil analysis was initiated. The genetic approach was initiated by a Russian geologist and soil expert Dokuczajew (1846-1903), who in 1877 commenced his work on the theory of climatic zoning of soils in the northern hemisphere. As a result of this work, he distinguished five basic soil-forming factors (parent material, climate, biota, topography, and time), formalised the soil definition and marked the observed layers of soil with letters. Dokuczajew shaped the genetic approach to soil 
science for dozens of years to come [Kowalkowski 1960, Kuźnicki et al. 1979]. The founding father of Polish soil science, Sławomir Miklaszewski, in his 1912 publication „Soils in Poland” wrote about "preponderant factors" in soil-forming: „Each soil, irrespective of its geographic location, was formed by weathering of exposed rocks of certain kinds; thus, being a product of orohydrographic, climatic and geological conditions of the country where it is found. Identical causes yield identical results". It was only in 1941 that a publication by a Swiss soil expert Hans Jenny resonated with a global audience. This work specified a general mathematical relationship combining the observed soil properties with independent factors determining soil-forming processes:

$$
s=f(c l, o, r, p, t, \ldots)
$$

where:

$s$ - soil properties,

$c l$ - regional climate,

$o$ - organisms,

$r$ - relief,

$p$ - parent material,

$t$ - time.

This form of the function of spatial reasoning about soils is still used nowadays. The aim of this article is to present Digital Terrain Models derivatives in the context of Digital Soil Mapping assumptions, and to show a few examples of their differentiated use in soil models with machine learning algorithms.

\section{Digital Soil Mapping}

DSM is creation of soil maps in a digital form (digital soil cartography), defined as a process of creating and filling soil data bases with help of models based on spatialtemporal relationships existing between various environmental covariates and soil [Lagacherie and McBratney 2016]. Nowadays it is a separate sub-discipline of soil science, developing dynamically since the beginning of this century (a scheme of DSM development by Minasny and McBratney 2016 is shown in Fig. 1). McBratney, Santos and Minasny in 2003 defined a formal conceptual framework for DSM, referring to the function for spatial reasoning about soils proposed by Jenny.

Confluence of various factors, such as improving access do spatial data (numerical altitude models and satellite imaging), improving computer computation capacity for processing high resolution data, development of data-mining tools, GIS technology evolution as well as increasingly common geostatistical applications has impacted gradual DSM development. At the same time, a worldwide demand for precise spatial data has been increasing and a rejuvenation process in many research centres and institutes which contributed to the development of soil science and DSM technology commenced. 


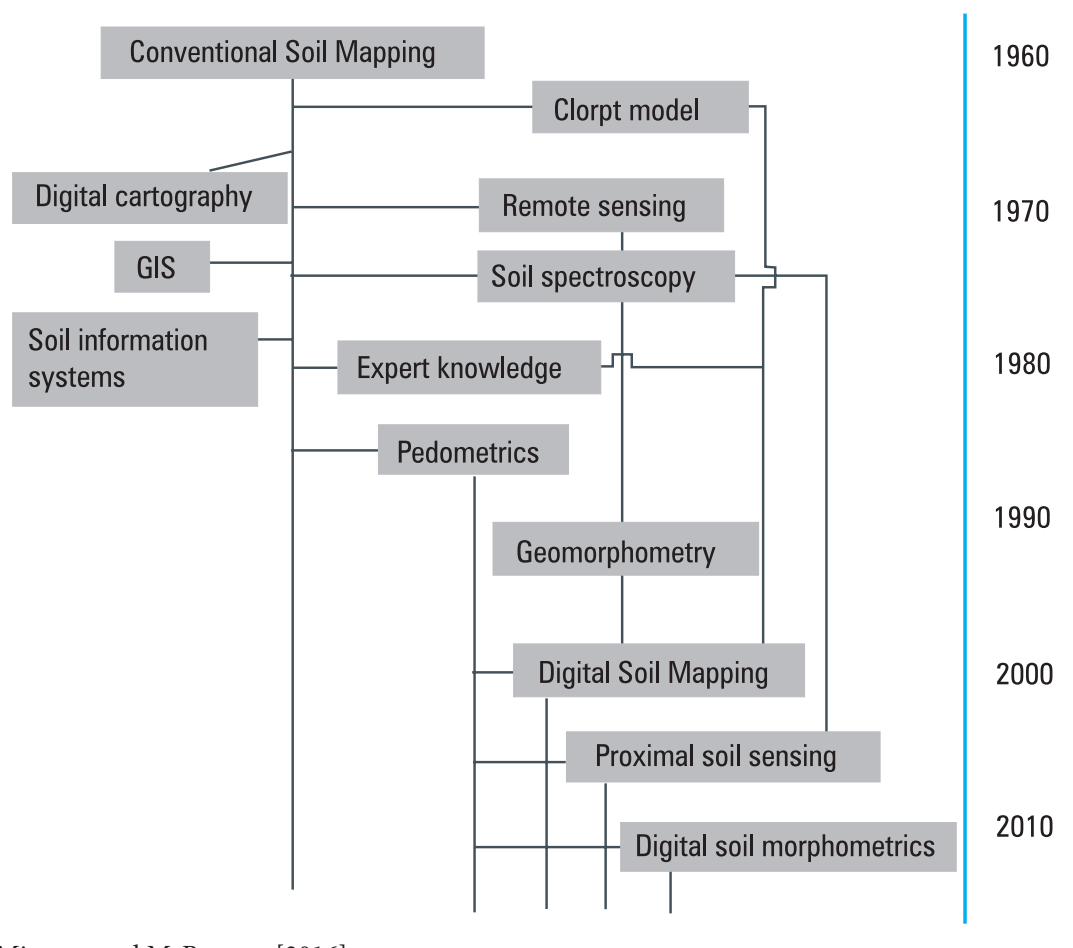

Source: Minasny and McBratney [2016]

Fig. 1. A diagram illustrating the evolution and confluence of different approaches in digital soil mapping

In the past decade, machine learning, and especially Random Forest technique [Vaysse and Lagacherie 2017, Teng et al. 2018, Wadoux et al. 2019a, Ellili-Bargaoui et al. 2020] has become one of the main methods of digital soil mapping. Breiman [2001] defines Random Forest as a set classifier based on a multitude of random decision trees, applying a set of binary rules to compute the target variable. In digital soil mapping, since information about the soil in a specific location is combined with its prognostic variables, binary rules relate to the factors determining the soil forming process. The final model, according to Stumpf [Stumpf et al. 2016], is arrived at by averaging the results for all the single trees at each point on the map. Single trees in the RF model should exhibit a range of variation, a result of which are continuous or discrete maps of soil properties. Recently, efficacy of Deep Learning methods application for DSM has been proven. Comparison of soil properties modelling in a multiscale approach with use of artificial neural networks [Behrens et al. 2018] and convolutional neural networks for prediction of total organic carbon for two varying soil depths, with uncertain measurement of soil properties [Padarian et al. 2019, Wadoux et al. 2019b] indicates higher prediction accuracy for convolutional neural networks, due to their ability to recognize contextual information. 
DSM requires three components: 1) data input (from field observations, laboratory, or statistics); 2) an algorithm based on spatial and non-spatial soil inference rules, encompassing mathematical or statistical models based on relationships between soil and environmental factors; 3) GIS analysis results, in a form of raster images of predicted soil type, along with an estimate of the accuracy of the division contours. The authors of the above-mentioned DSM conceptual development [2003] proposed introduction of a function of spatial inference about soils, which was called SCORPAN. The name derives from the initial letters in the words describing soil-forming factors [McBratney 2003]:

$$
S_{C}=f(s, c, o, r, p, a, n)+e
$$

where:

$S_{C}$ - the soil type being formed,

$s$ - soil (soil can be used as a factor as it can be predicted on the base of its properties or the properties of its soil class or other properties),

$c$ - climate,

$o$ - organisms,

$r$ - relief,

$p$ - parent material,

$a$ - age,

$n$ - nodes,

$e$ - spatially corelated residual.

Such an approach to soil modelling is called a soil-landscape approach, but also physiographic or ecological, as it is based on geological, geomorphological and relief data as well as soil-water relationship and vegetation cover [Gessler et al. 1995, Lavelle 2000, Xiong et al. 2014 among others]. A soil-landscape model presents a simplified version of soil cover, eliminating soil units of a smaller area, yet it well "assigns" soil units to other landscape elements such as terrain features, vegetation cover or lithology [Białousz et al.].

Relief is one of the most significant environmental elements as it constitutes a record of exogenous processes, being their result and at the same time affecting the course of soil-forming and hydrographic processes as well as on vegetation cover (Wieczorek and Żyszkowska, 2011). At the same time, the quality and accuracy of currently available altitude data allows a fully accurate quantitative description of the examined area.

\section{DTM derivatives used in DSM}

The quantitative terrain description process used in digital soil mapping is called parameterization of the area. It makes use of morphometric indicators, also called terrain attributes or terrain derivatives, and the term DTM derivates is used in reference to a numerical terrain model. Primary attributes are values computed directly from DTM, 
while secondary attributes (also called compound attributes) comprise a combination of primary features constituting a base for characterization of spatial variability of the processes taking place in the landscape. Among the most popular terrain indicators computed from DTM are hypsometry, slope gradient, profile curvature (sinusoidal), planar curvature (tangential), the length of surface run-off, flow direction and flow accumulation, catchment area and topographic wetness index. While shaded relief is an extremely useful parameter aiding detection of terrain features, it is not a classic DTM derivative, as its form depends on two extra variables, namely the simulated height of the sun above the horizon and its position on the horizon (azimuth). With a sufficient DTM resolution and an appropriate choice of parameters simulating height of the sun, areas where the terrain is not flat start to show in the shaded relief image. These can be microforms, mezzo-forms, sets of micro- or mezzo-forms which may correspond to homo- or heterogenic geocomplexity(es) of a specific category [Kot 2009]. It is also worth mentioning that shaded relief is used to create topographic maps of various planets, e.g., a map of Mercury published in 2016 by NASA (NASA, 2016). DTM derivatives are used in the digital modelling of soil water erosion [Pijanowski 2013], and as Fijałkowska [2021] proves, the accuracy and detail of elevation data sources has a significant impact on the derivative values (map of slopes, map of flow directions, map of runoff accumulation).

Hypsometry, being a starting point for other DTM derivatives, is most often represented by the GRID or TIN models.

Slope gradient (first derivative) is a value describing the rate of height change in the direction of the steepest slope. Slope gradient corelates with the impact of gravitation on surface run-off of water and other materials, and that is why it is of enormous significance both in hydrology and geomorphology. It also affects the run-off speed vector both on the surface and underground, and hence soil saturation, the degree of erosion risk, soil-forming, and many other important processes. Many formulas to calculate the slope gradient can be found in literature. These can be classified in accordance with the number of nodes, commonly called neighbours, which the algorithm uses. Batson [Batson et al. 1975] made use of two neighbouring nodes, considering the slope gradient value in two directions only, which in justified cases, is the fastest algorithm. An example of such use can be modelling of reflection in SLAR radar images (Side-Looking Airborne Radar). While the most used algorithms in the 80s were algorithms based on four or eight neighbours, applying the formulas proposed by Fleming and Hoffer [1979] (for four neighbours) and (for eight ones) by Ritter [1987], since the end of the 90s scientists have also been considering the central node, surrounded by the eight neighbouring nodes. An example of such an algorithm is Burrough's formula [Burrough and McDonell 1998], currently used in popular GIS applications (Fig. 2a). 
a.

$$
\begin{aligned}
& s=\operatorname{arctg} \sqrt{\left(\frac{d z}{d x}\right)^{2}+\left(\frac{d z}{d y}\right)^{2} * 57.3} \\
& \frac{d z}{d x}=\frac{\left(\frac{(c+2 f+i) * 4}{w g h t 1}\right)-\left(\frac{(a+2 d+g) * 4}{w g h t 2}\right)}{8 * \text { res }}
\end{aligned}
$$

$$
\frac{d z}{d y}=\frac{\left(\frac{(c+2 h+i) * 4}{w g h t 3}\right)-\left(\frac{(a+2 b+g) * 4}{w g h t 4}\right)}{8 * \text { res }}
$$

b.

\begin{tabular}{|c|c|c|}
\hline$a$ & $b$ & $c$ \\
\hline$d$ & $e$ & $f$ \\
\hline$g$ & $h$ & $i$ \\
\hline
\end{tabular}

Fig. 2. (a) A Burrough's formula for slope (b) marking of cells in surface scanning window with ArcGIS algorithm at work

Curvature (second derivative) indicates the rate of first derivative change (slope gradient) in a specific direction: profile curvature - perpendicular to the ground; planar - parallel to the ground. The values of curvature assume a range of values depending on the differences in terrain height, while with absence of plane curvature in a given direction the curvature value always stands at zero. Profile curvature shows change in surface run-off speed and transport of sediment speed. Planar curvature is a measure of topographic convergence and divergence, that is a tendency for the surface run-off to concentrate or diverge. In order to identify geomorphological units, both these curvatures are used: the planar one to classify terrain forms (valleys, hill tops, edges) and a profile one to differentiate between concave and covex forms [Wilson and Gallant 2000]. Values for planar and profile curvatues for four schematic terrain forms: mountain (A), valley (B), anticline (C) and hill (D) presents Table 1 [Radło- Kulisiewicz 2019].

Curvatures are usually calculated for each raster cell with use of a fourth order polynomial. The formulas used in ESRI software are presented in Fig. 3a.

Flow direction and flow accumulation (first derivatives) determine the way how rainfall water spreads over the area. For each cell in DTM raster, the steepest downward slope to a neighbour cell is computed, and its direction is stored in a new raster (flow direction raster) as a coded number - the proper azimuth direction (N, NE, E, ES, S, SW, $\mathrm{W}, \mathrm{WN}$ ) or No Data in case of the lowest value of all the surrounding cells. A raster that for each cell indicates how many cells have their water flow into the cell is the accumulated flow raster. These both derivatives of DTM are used for next second derivatives.

Length of surface run-off (second derivative) is the diatnce between a point in the catchment area and the point of water outflow, measured along the flow direction (not in a straight line) In GIS software it is computed with use of DTM and the raster of flow directions. 
a. $K=A x^{2} y^{2}+B x^{2} y+C x y^{2}+D x^{2}+E y^{2}+F x y+G x+H y+I$

$\mathrm{A}=[(\mathrm{Z} 1+\mathrm{Z3}+\mathrm{Z} 7+\mathrm{Z9}) / 4-(\mathrm{Z} 2+\mathrm{Z} 4+\mathrm{Z} 6+\mathrm{Z8}) / 2+\mathrm{Z} 5] / \mathrm{L} 4$

$\mathrm{B}=[(\mathrm{Z} 1+\mathrm{Z3}-\mathrm{Z} 7-\mathrm{Z} 9) / 4-(\mathrm{Z} 2-\mathrm{Z} 8) / 2] / \mathrm{L} 3$

$\mathrm{C}=[(-\mathrm{Z} 1+\mathrm{Z3}-\mathrm{Z} 7+\mathrm{Z9}) / 4+(\mathrm{Z} 4-\mathrm{Z} 6)] / 2] / \mathrm{L} 3$

$\mathrm{D}=[(\mathrm{Z} 4+\mathrm{Z} 6) / 2-\mathrm{Z} 5] / \mathrm{L} 2$

$\mathrm{E}=[(\mathrm{Z} 2+\mathrm{Z} 8) / 2-\mathrm{Z} 5] / \mathrm{L} 2$

$\mathrm{F}=(-\mathrm{Z} 1+\mathrm{Z3}+\mathrm{Z7}-\mathrm{Z9}) / 4 \mathrm{~L} 2$

$\mathrm{G}=(-\mathrm{Z} 4+\mathrm{Z6}) / 2 \mathrm{~L}$

b.

$\mathrm{H}=(\mathrm{Z} 2-\mathrm{ZB}) / 2 \mathrm{~L}$

$\mathrm{I}=\mathrm{Z5}$

Source: esri.com

Fig. 3. (a) The curvature formulas used in ArcGIS (b) Altitude marked in the nine neighbouring pixels; $\mathrm{L}$ - raster resolution

Table 1. Curvature values for sample terrain forms

\begin{tabular}{|c|c|c|c|c|c|}
\hline Planar & Profile & Form shape & Planar & Profile & Form shape \\
\hline $\begin{array}{c}\text { convex } \\
(+)\end{array}$ & $\begin{array}{c}\text { convex } \\
(-)\end{array}$ & ( & $\begin{array}{c}\text { convex } \\
(+)\end{array}$ & $\begin{array}{c}\text { concave } \\
(+)\end{array}$ & B \\
\hline $\begin{array}{c}\text { concave } \\
(-)\end{array}$ & $\begin{array}{c}\text { concave } \\
(+)\end{array}$ & C & $\begin{array}{c}\text { concave } \\
(-)\end{array}$ & $\begin{array}{c}\text { convex } \\
(-)\end{array}$ & D \\
\hline
\end{tabular}

Source: Radło-Kulisiewicz [2019] modified

Catchment area (second derivative) - is an image of neighbouring but separate catchment areas, generated from the image of flow directions obtained on the base of slope gradients and curvature. As far back as the 40s of the previous century such an approach to quantitative morphology was perceived by hydrologists as a measure of landscape divisions and expressed as drainage density, indicating the total length of potential run-offs on the examined surface $\left(\mathrm{m} \cdot \mathrm{m}^{-2}\right)$ [Schilacci et al. 2015].

Topographic wetness index (also called Compound Topographic Index; second derivative) refers to the relative altitude of the examined area. The index value oscillates 
around zero, indicating areas elevated above the average altitude for positive values and lowered for negative ones. GIS applications often make use of formula 4 [Wilson and Gallant 2000]:

$$
T W I=\ln \left(\frac{A s}{\operatorname{tg} B}\right)
$$

where:

As - the area of the local catchment area,

$B$ - elevation gradient.

Shaded relief is defined as land relief, at a given angle of incidence of sunlight and a given height of light source.

Figure 4 shows an example set of DTM derivatives in grid format $(\mathrm{GSD}=20 \mathrm{~m})$ for the area located in north-eastern Poland, in the Masurian Lake District, in the Olsztyn district (area about $100 \mathrm{~km}^{2}$ ). The processing was performed with the use of ESRI algorithms in the ArcMap application, respectively: Fig. 4b - "slope" function, Fig. 4c - "plan curvature", Fig. $4 \mathrm{~d}$ - "hill shade" with parameters: azimuth $315^{\circ}$, sunlight position: $60 \mathrm{~m}$ over the horizon, Fig. $4 \mathrm{e}$ - result of formula TWI, Fig. $4 \mathrm{f}$ - "flow accumulation".
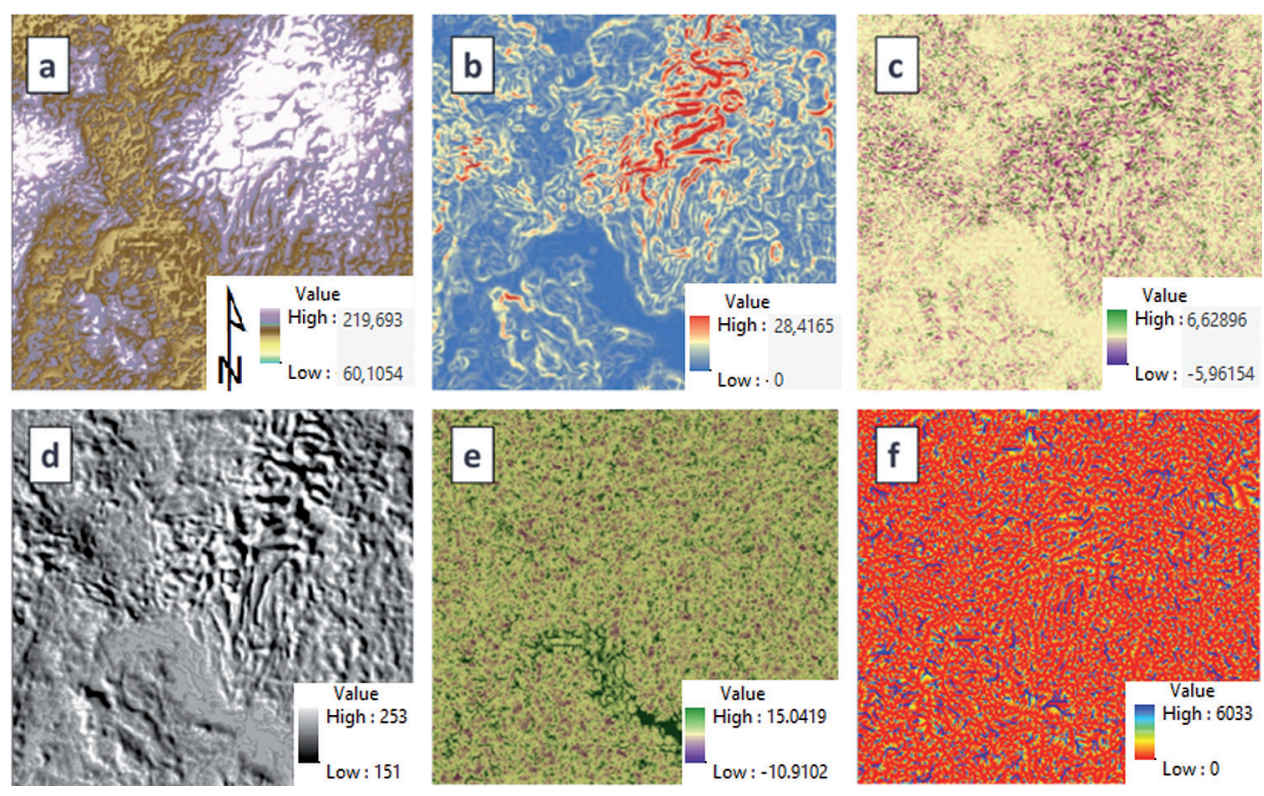

Fig. 4. (a) DTM transformations: hypsometry - a starting point for other DTM derivatives, (b) slope gradient - a value describing the rate of height change in the direction of the steepest slope, (c) planar curvature - the rate of the slope gradient - parallel to the ground, (d) shaded relief - land relief, at a given angle of incidence of sunlight and a given height of light source, (e) TWI - relative altitude of the examined area, (f) flow accumulation a cumulative count of the number of pixels that naturally drain into outlet (by author) 
It is worth noting that even before formalising DSM, terrain indicators based on DTM were used to model specific soil features, selected indicators are shown in Table 2 [Dobos et al. 2002].

In digital soil mapping terrain features are the most used predicators, used both to map specific soil classes and soil cover of whole regions. The methodology applied in prognostic research into spatial soil distribution with use of digital terrain analysis and multinomial logistic regression was developed for Vestfold County in the south - east of Norway [Debella-Gilo et al. 2007]. In the examined area, sixteen terrain features had been analysed for their corelations with the soil class under examination, and because of these analyses the following terrain features were established to be the most significant ones allowing accurate prediction of soil class: hypsometry, the length of the surface run-off, topographic wetness index, slope gradient, sun exposition and its duration. Basing on the analyses, these terrain indicators were then used as variables in logit models for each of the 13 soil classes examined. Logit models provide two kinds of statistics: factors of the impact of variables $X_{i}$ on the examined phenomenon $Y$ and

Table 2. Selected most common terrain indicators used to model specific soil variables

\begin{tabular}{|c|c|c|c|}
\hline Authors & Soil variables & Terrain parameters & $\begin{array}{c}\text { Resolution } \\
\text { DTM [m] }\end{array}$ \\
\hline $\begin{array}{l}\text { Gessler et al. } \\
{[1995]}\end{array}$ & $\begin{array}{l}\text { A-horizon depth, } \\
\text { solum depth, E-horizon } \\
\text { presence, or absence }\end{array}$ & plan curvature CTI & 20 \\
\hline $\begin{array}{l}\text { Bell et al. } \\
{[1992]}\end{array}$ & Soil drainage classes & $\begin{array}{l}\text { slope, slope-curvature ratio, elevation } \\
\text { above local stream, slope gradient to } \\
\text { local stream, distance to local stream, } \\
\text { distance to local drainage way }\end{array}$ & 30 \\
\hline $\begin{array}{l}\text { Bell et al. } \\
{[1994]}\end{array}$ & $\begin{array}{l}\text { A-horizon and carbonate } \\
\text { depth Bell j.c. }\end{array}$ & $\begin{array}{l}\text { slope gradient, curvature, drainage } \\
\text { path, specific catchment area, elevation, } \\
\text { wetness index, stream power, drainage }\end{array}$ & 10 \\
\hline $\begin{array}{l}\text { Moore et al. } \\
{[1993]}\end{array}$ & $\begin{array}{l}\text { A-horizon thickness, } \\
\text { organic matter content, } \\
\text { pH, extractable P, and silt } \\
\text { and sand contents }\end{array}$ & slope and wetness indices & 15,24 \\
\hline $\begin{array}{l}\text { Gessler et al. } \\
{[2000]}\end{array}$ & $\mathrm{C}$ and soil mass & $\begin{array}{l}\text { flow direction, flow accumulation, slope } \\
\text { gradient, profile and plan curvature, } \\
\text { CTI }\end{array}$ & $2,4,6,8,10$ \\
\hline $\begin{array}{l}\text { Thomas } \\
\text { et al. [1999] }\end{array}$ & soil types & $\begin{array}{l}\text { altitude, slope, aspect, profile and plan } \\
\text { curvature, distance to the thalweg }\end{array}$ & 50 \\
\hline $\begin{array}{l}\text { Dobos et al. } \\
{[2000,2001]}\end{array}$ & soil types & PDD, slope, elevation & 1000 \\
\hline
\end{tabular}

Source: Dobos et al. [2002] modified 
on probability $P_{i}$ determining the extent to which the model was adjusted for actual relationships [Domański 1998]. The proposed method was estimated as "reliable", except for those soils, whose forming is impacted by other factors, e.g., human activity rather than by topography. In 2013, similar research was conducted for the northern Egypt regions [Abdel-Kader 2013], making use of terrain attributes and spectral values from Landsat images to estimate soil classes with use of logit models. The results of the research indicated that the most significant terrain features affecting spatial distribution of soil classes are hypsometry, valley depth, ridge, and valley floor curvature as well as wetness index. The logit models were the base for development of predictive soil maps.

An interesting aspect concerning use of terrain features in digital soil mapping is choice of DTM resolution. In the research conducted in the north of the Czech Republic the impact of altitude data resolution on colluvial soil mapping was tested [Penížek et al. 2016]. DTM of 1, 2, 3, 5, 10, 20 and 30-metre resolution was tested and then selected derivatives were computed for each variant. In the process of prediction of a given soil type presence machine learning was used, among others the following four training algorithms: neural networks, boosted tree, random forest and classification and regression trees). Model training and validation were based on 111 soil profiles examined on a regular sampling grid. The research indicated no significant effect of the change in the source data resolution on the accuracy of the model predictions and no general trend in the overall soil cover prediction was observed. Interestingly, for each of the resolutions tested at least one model exhibited high measurement accuracy and the compatibility of training points with reference data exceeded $70 \%$.

Carré [Carré et al. 2008] used and compared two approaches: "bottom-up" and "up-down" to model contours of soil divisions in the $1: 25,000-1: 250,000$ scale range. In the former, soil and terrain features were classified in combination, to obtain taxonomic units which were later generalised to the contours representing map units of $1: 250,000$ scale. The up-down approach consisted in classification of auxiliary data only (hypsometry and wetness index), whose results were aggregated into taxonomic units and generalised to the $1: 250,000$ scale. The results obtained confirmed the usefulness of the up-down approach to prepare soil maps in a digital form as well as the fact that these can be a good alternative to correction of soil data bases already in existence but containing geometrical mistakes before applying the bottom-up approach.

\section{Summary and conclusions}

Digital soil mapping uses advanced and constantly developing artificial intelligence methods and its invariably essential element continues to be, also constantly evolving, a numerical terrain model and its derivatives. Currently, access do altitude data from various sources, which means varying resolution, accuracy, timeliness, spatial range, recording format and model is enormous. This results from the advanced technology and constantly increasing possibilities of obtaining accurate data in a short time. Use of morphometric indicators as proven prognostics in determining specific oil properties in the profile as well as use of auxiliary data in modelling soil cover in regions 
has become commonplace in digital soil mapping. It seems that the main task for the coming years concerning DSM in addition to raising the spatial resolution of soil data worldwide is establishing the standards of accuracy and evaluation of the results obtained. The worldwide effects of this standardization in the DSM technology of soil mapping or examination of threats to agriculture such as erosion, will consist in not only better protection and mode effective use of agricultural areas but also enormous financial gains.

\section{References}

Abdel-Kader F.H. 2013. Digital Soil Mapping Using Spectral and Terrain Parameters and Statistical Modelling Integrated into GIS-Northwestern Coastal Region of Egypt. Developments in Soil Classification. Land Use Planning and Policy Implications, Springer, 353-371.

Batson R.M., Edwards K., Eliason E.M. 1975. Computer-generated shaded - relief images. Journal of Research US Geology.

Behrens T., Zhu A.X., Schmidt K., Scholten T. 2010. Multi-scale digital terrain analysis and feature selection for digital soil mapping. Geoderma, Elsevier.

Behrens T., Schmidt K., MacMillan R.A., Viscarra Rossel R.A. 2018. Multi-scale digital soil mapping with deep learning. Naturesearch, Scientific Reports.

Bell J.C., Cunningham R.L., Havens M.W. 1992. Calibration and Validation of a Soil-Landscape Model for Predicting Soil Drainage Class. Soil Society of America Journal.

Bell J.C., Cunningham R.L., Havens M.W. 1994. Soil Drainage Class Probability Mapping Using a Soil-Landscape Model. Soil Society of America Journal.

Białousz S., Chmiel J., Fijałkowska A., Różycki S., Pluto-Kossakowska J. 2010. Opracowanie i testowanie metod wykorzystania zdjęć satelitarnych oraz technologii GIS do aktualizacji małoskalowych baz danych przestrzennych o glebach i krajobrazie. Raport końcowy z projektu badawczego.

Breiman L. 2001. Random Forest. Machine Learning, Springer.

Burrough P.A., McDonell R.A. 1998. Principles of Geographical Information Systems. Oxford University Press, New York, 190.

Carré F., Reuter H., Daroussin J., Scheurer O. 2008. From a Large to a Small-Scale Soil Map: Top-Down Against Bottom-Up Approaches. In: Digital Soil Mapping with Limited Data. A.E. Hartemink, A. McBratney, M. Mendonça-Santos (eds). Springer.

Debella-Gilo M., Etzelmuller B., Klakegg O. 2007. Digital Soil Mapping Using Digital Terrain Analysis and Statistical Modeling Integrated into GIS: Examples from Vestfold County of Norway, Semantic Scholar.

Dobos E., Micheli E., Baumgardner M.F., Biehl L., Helt T. 2000. Use of combined digital elevation model and satellite radiometric data for regional soil mapping. Geoderma, 97, 3-4, September, 367-391.

Dobos E., Montanarella L., Nègre T., Micheli E. 2001. A regional scale soil mapping approach using integrated AVHRR and DEM data. International Journal of Applied Earth Observation and Geoinformation.

Dobos E., Norman B., Worstell B., and et al. 2002. The use of DEM and satellite data for regional scale soil databases. Agrokémia és Talajtan.

Dobos E., Carré F., Hengl T., Reuter H.I., Tóth G. 2006. Digital Soil Mapping as a support to production of functional maps. Office for Official Publications of the European Communities, Luxemburg. 
Domański H. 1998. Wielonomialny model logitowy. Przykład zastosowania i interpretacja. ASK, 7, 67-82.

Ellili-Bargaoui Y., Malone B.P., Michot D., Minasny B., Vincent S., Walter C., Lemercier B. 2020. Comparing three approaches of spatial disaggregation of legacy soil maps based on the Disaggregation and Harmonisation of Soil Map Units Through Resampled Classification Trees (DSMART) algorithm. Soil, 6, 371-388.

Fijałkowska A. 2021. Analysis of the Influence of DTM Source Data on the LS Factors of the Soil Water Erosion Model Values with the Use of GIS Technology, MDPI.

Fleming M.D., Hoffer R.M. 1979. Machine Processing of Landsat MSS Data and DMA Topographic Data for Forest Cover Type Mapping, Laboratory for Applications of Remote Sensing, Purdue University, West Lafayette, IN, LARS Technical Report 062879.

Gessler P.E., Chadwick O.A., Chamran F., Althouse L., Holmes K. 2000. Modeling Soil Landscape and Ecosystem Properties Using Terrain Attributes. Soil Society of America Journal.

Gessler P.E., Moore I.D., McKenzie N.J., Ryan P.J. 1995. Soil-landscape modelling and spatial prediction of soil attributes. International Journal of Geographical Information Systems.

Hartemink A., McBratney A., Lourdes Mendoca-Santos M. 2008. Digital Soil Mapping with limited data, Springer.

Jenny H. 1941. Factors of Soil Formation: A System of Quantitative Pedology. Dover Publications.

Kot R. 2009. Próba ujednolicenia rangi jednostek rzeźby terenu dla delimitacji geokompleksów wybranych krajobrazów nizinnych. Problemy Ekologii Krajobrazu.

Kowalkowski A. 1960. Projekt nomenklatury poziomów glebowych. Roczniki Gleboznawcze, IX.

Kuźnicki F., Białousz S., Skłodowski P. 1979. Podstawy gleboznawstwa z elementami kartografii i ochrony gleb. PWN.

Lagacherie P., McBratney A. 2006. Spatial Soil Information Systems and Spatial Soil Inference Systems: Perspectives for Digital Soil Mapping, Development of Soil Science.

Lavelle P. 2000. Ecological challenges for soil science. Soil Science.

McBratney A., Santos M., Minasny B. 2003. On Digital Soil Mapping, Geoderma.

Miklaszewski S. 1912. Gleby ziem polskich. Warszawa.

Minasny B., McBratney A.B. 2016. Digital soil mapping: A brief history and some lessons. Geoderma.

Moore I.D., Gessler P.E., Nielsen G.A., Peterson G.A. 1993. Soil attribute prediction using terrain analysis.

NASA. 2016. https://science.nasa.gov/2016-transit-mercury

Padarian J., Minasny B., McBratney A. 2019. Using deep learning for digital soil mapping. Soil, $5,79-89$.

Penížek V., Zádorová T., Kodešová R., Vaněk A. 2016 Influence of Elevation Data Resolution on Spatial Prediction of Colluvial Soils in a Luvisol Region, PLOS One.

Pijanowski J.M., Radecki-Pawlik A., Wałęga A., Wojkowski J. 2013. Evaluation of soil water erosion risk in the Mściwojów water reservoir drainage basin based on numeric modelling. Geomatics, Land Management and Landscape, 1, 83-95.

Radło-Kulisiewicz M. 2019. Wykorzystanie pochodnych DTM w modelowaniu pokrywy glebowej w krajobrazie młodoglacjalnym dla bazy danych o glebach o poziomie uogólnienia odpowiadającym mapom w skali 1: 250 000, rozprawa doktorska. Archiwum Politechniki Warszawskiej.

Ritter P. 1987. A vector-based slope and aspect generation algorithm. Photogrammetric Engineering and Remote Sensing, 53-8, 1109-1111. 
Schillaci C., Braun A., Kropáček J. 2015. Terrain analysis and landform recognition. Geomorphological Techniques. DOI:10.13140/RG.2.1.3895.2802

Strzemski M. 1957. Zarys rozwoju pojęcia i definicji gleby. Zakład Gleboznawstwa IUNG w Puławach.

Stumpf F., Schmidt K., Behrens T., Schondrodt-Stitt S., Buzzo G., Dumperth C., Wadoux A., Xiang W., Schoelten T. 2016. Incorporating limited field operability and legacy soil samples in a hypercube sampling design for digital soil mapping. Journal of Plant Nutrition and Soil Science.

Teng H., Viscarra Rossel R., Behrens T. 2018. Updating a national soil classification with spectroscopic predictions and digital soil mapping. Catena.

Thomas A.L., King D., Dambrine E., Couturier A., Roque J. 1999. Predicting soil classes with parameters derived from relief and geologic materials in a sandstone region of the Vosges mountains (Northeastern France). Geoderma, 90, 3-4, July, 291-305.

Vaysse K., Lagacherie P. 2017. Using quantile regression forest to estimate uncertainty of digital soil mapping products. Geoderma.

Wadoux A., Brus D.J., Heuvelink G.B.M. 2019. Sampling design optimization for soil mapping with random forest. Geoderma.

Wadoux A., Padarian J., Minasny B. 2019. Multi-source data integration for soil mapping using deep learning. Soil, 5, 107-119. https://soil.copernicus.org/articles/5/107/2019

Wieczorek M., Żyszkowska W. 2011. Geomorfometria - parametry morfometryczne w charakterystyce rzeźby terenu. Polski Przegląd Kartograficzny.

Wilson J., Gallant J. (ed.). 2000. Terrain analysis. John Wiley and Sons.

Xiong X., Grunwald S., Myers D.B., Kim J., Harris W.G., Comerford N.B. 2014. Holistic environmental soil-landscape modeling of soil organic carbon. Elsevier.

\footnotetext{
Małgorzata Radło-Kulisiewicz

Warsaw University of Technology,

Department of Photogrammetry, Remote Sensing and Spatial Information Systems

pl. Politechniki 1, 00-661 Warszawa

e-mail: malgorzata.radlo@pw.edu.pl

ORCID: 0000-0002-8666-3838
} 